\title{
The effect of apple (Malus domestica) juice on the damage of mice liver cells due to paracetamol treatment
}

\author{
Anthony Hartanto, Murnisari Darjan, Silvi Kintawati \\ Department of Oral Biology Faculty of Dentistry Universitas Padjadjaran
}

\begin{abstract}
Liver is an important organ for body metabolism process. Liver disease is one of serious health problems in developing countries including Indonesia. Liver damage is caused by viral infection, toxic agent exposure (medications, alcohol), hormonal disturbance, neoplasm and autoimmune diseases. The use of high dose paracetamol to reduce pain also leads to liver damage. Apple (Malus domestica) juice is a natural anti oxidant agent. This laboratory experimental study was performed to discover the effect of giving apple juice on damaged cell regeneration due to the use of paracetamol. The study was performed in 21 male mice from Swiss-Webster strain that were divided into group I, II, and III. Group I served as control while group II received $1 \mathrm{mg} / \mathrm{ml}$ paracetamol dose for 5 days and Group III received $1 \mathrm{mg} / \mathrm{ml}$ paracetamol for 5 days and $1 \mathrm{ml}$ of apple juice on the $5^{\text {th }}$ to $10^{\text {th }}$ day. The observation on the mice liver cells was conducted using light microscope with 400x magnification to get the number of necrotic liver cells per view field. The results of this study showed a difference in the number of necrotic liver cells between Group II and III. ANOVA statistical test $(\alpha=0,05)$ concluded that apple juice significantly helps regeneration process in damaged liver cells caused by paracetamol.
\end{abstract}

Key words: Liver cells, paracetamol, apple juice

\section{INTRODUCTION}

Liver disease is one of the serious health problems in developing countries, including Indonesia. ${ }^{1}$ The liver disease is especially caused by the presence of toxic agents (alcohol, drugs), infection (virus, bacteria, parasites), disorders in blood vesels or spleen secretion and tumour (both primary and metastatic tumours). ${ }^{2}$

Liver plays an important role in metabolism process for all food absorbed from the intestine. In addition to the digested materials that are kept in the liver, the blood flow through port a hepatic vein also brings various toxic materials in the liver that are then detoxified and excreted by the liver. ${ }^{3}$
Liver, as the main organ in the metabolism and detoxification process of the drugs in the body, has a high risk for damage caused by most chemicals contained in drugs. ${ }^{4}$

Paracetamol (acetaminophen) is a drug of choice replacing aspirin that is very effective in managing pain and fever but the anti-inflammation activity of this drug is very weak. Paracetamol is used widely by the people due to its good analgesic and anti-pyretic activities, fewer side effects compared to aspirin and is an OTC drug. ${ }^{5}$

The therapeutic dose of paracetamol for adult is $300 \mathrm{mg}-1 \mathrm{~g}$ per dose with a maximum $4 \mathrm{~g}$ per day. ${ }^{6}$ Paracetamol with a dose higher than $4 \mathrm{~g}$ a day will lead to dose dependent drug hepatotoxity 
and will rapidly causes damages of liver cells, especially in centrilobular area. ${ }^{7}$

Paracetamol experiences metabolism and detoxification by liver cell oxidation system. The use of paracetamol produces a reactive metabolite that is toxic, which in the therapeutic dose is detoxified through biding in glutation. In high dose paracetamol use, the metabolite will be deposited, reducing glutation level in the liver and bound covalently to liver cell macromolecules leading to heart cell centrilobular necrosis. ${ }^{8}$

Oxidation process of carbohydrates, fat, proteins and body cell DNA can be inhibited by giving antioxidant. ${ }^{9}$ This is also supported by Lata et al. ${ }^{10}$ who stated that antioxidant can protect cell membrane and organels from damages due to free radicals during oxidation process.

A substance that functions as antioxidant and play important role in wound healing is vitamin C. ${ }^{11}$ Hernani and Rahardjo ${ }^{12}$ also stated that vitamin $\mathrm{C}$ effectively function as antioxidant agent. Body needs vitamin C. Lack of vitamin C in the blood may lead to several diseases such as liver disease, asthma, diabetes and cancer.

In $100 \mathrm{~g}$ of aple, there are $5 \mathrm{mg}$ of vitamin C. ${ }^{11}$ In addition to vitamin $\mathrm{C}$ which is a strong anti oxidant, aple also have flavonoid, another antioxidant substance. Flavonoid is a pigment agent in plants that give protection towards the damaging free radical activities. ${ }^{11}$

Boyer and Liu ${ }^{13}$ stated that apple have high antioxidant activities. Antioxidant activity in 100 $\mathrm{g}$ of fresh apple is similar to antioxidant activity of $1.5 \mathrm{~g}$ vitamin $\mathrm{C}$.

Based on the above explanation, the author was interested in studying the effect of apple juice to damaged liver cell regeneration caused by paracetamol. This study was performed to see whether apple juice can be used as one of the alternative therapy to help liver damage improvement.

\section{MATERIALS AND METHODS}

The experimental animals used as objects in this study were 21 Swiss Webster strain male mice, 6 weeks old with a weight of more or less 1825 grams. The experimental animals were divided into Group I (control), Group II (intoxication), and Group III (treatment).
Group I consisted of 3 mice and receive adequate food and drink. The mice received laparotomy on day-7. Group II consisted 9 mice and was given paracetamol dose of $1 \mathrm{mg} / \mathrm{ml}$ per oral per mice up to day 5 . Mice then received laparotomy on day 7, day 9, and day 11, 3 mice each. Meanwhile, Group III consisted of 9 mice and was given paracetamol dose of $1 \mathrm{mg} / \mathrm{ml}$ per oral each until day 5 . In addition the mice received apple juice, $1 \mathrm{ml}$ per oral per mice until on day 5 to day 10. After that the mice received laparotomy on day 7 , day 9 and day $11 ; 3$ mice each.

During the study, the mice received adequate food and drink. The surgery to got liver organ from the mice was done using laparotomy technique. After the liver was taken out from the abdomen, hystological preparations using Hematoxillin-Eosin he were then prepared.

Necrotic liver parenchyme cell count was performed by observing cell morphological change appearance, i.e. the presence of cell membrane damage, various cell nucleous appearance starting from picnotist, cariorexis, or cariolysis and non homogenous cytoplasm. ${ }^{4}$

After the hystological preparation and HE dying were finished, the liver tissue changes were observed using light microscopy per view field with a magnification of 100x (objective lens 10x and ocular lens 10x). To more clearer for the changes occurred, an observation with 400x magnification was performed. Normal and necrotic liver cells were counted by looking at liver cell morphological change observation seen in each view field. The number necrotic liver cells were then compared to the total cells observed per view field (normal and necrotic liver cells).

Liver tissue preparation from one mice was observed per view field with a total of 12 view fields. The 12 view fields were taken by moving the preparation to the right, one rotation for 4 times, down one rotation, left one rotation for four times and then down again one rotation and right again one rotation for four times. The same observation method was also applied for the control group consisting of 3 mice.

Data collected was tested statistically using ANOVA (Analysis of Variance) method to see whether the two treatment groups give significant results based on the different time and treatment. 


\section{RESULTS}

On day 7, the observation on Group II who received paracetamol treatment only showed an appearance of necrotic liver cells with various damage appearances in the cell nucleous (picnosis, cariorexis, and cariolysis) and non homogenous cytoplasm surrounded by non intact cell membrane. This led to sinusoid appearance that has experienced expansion and irregular. The liver cells were no longer in radial arrangement towards central vein as the center of the lobule according to classic lobule concept. Meanwhile, observation to Group III who received paracetamol and continued by apple juice shows an appearance of reduced necrotic cell number compared to Group II.

Observation on Group II day 9 shows necrotic liver cells appearance in lower number compared to what was seen on day 7 for Group II. The liver cells look radially arranged towards the central vein as the lobule center with most of sinusoids look regular despite sinusoid expansion in one or two places. There was reduced number of necrotic liver cells compared to day 9 Group II and Group III day 7 because there was cell mitotic activities showing enlarged nucleous or two nuclei in one cell.

On day 11, observation on Group II showed an appearance that most of liver parenchymal cells experience mitotic activities shown by enlarged nucleous or two nuclei in one cell. This cell regeneration process caused the number of necrotic liver cells become lower compared to Group II and III on day 9. Liver cells start to be arranged regularly and radially towards the lobule center, i.e. central vein, despite sinusoid expansion in some placess. In Group II, on day 11 , the liver cells appearance was nearly normal although some cells are still experiencing necrosis in some places.

The ANOVA test results concluded that apple juice could be used as an alternative therapy to help the regeneration of damaged liver cells caused by paracetamol consumption.

\section{DISCUSSION}

Observation on day 7 showed that the liver cells around the central vein underwent a lot of necrosis which might be caused by the toxic effect of high dose paracetamol for five days. The necrotic cells showed an appearance of damaged cell membrane as a reaction on active metabolite of paracetamol that weaken membrane structure. In these cells, nucleous damage appearance was also seen in the form of picnosis, cariorexis and cariolysis. This was in accordance to the statement of Robbins et al. ${ }^{4}$ that cell necrosis was a cell morphological changes accompanied by membrane damages. The damage in cell nucleous can take the form of picnosis giving appearance of shrinking nucleous with irregular border, cariorexis showing an appearance of destroyed nucleous with chromatin parts scattered in cell cytoplasm and cariolysis that shows an appearance of destroyed and missing nucleous.

Distribution zone in asinus concept was performed based on the location of the liver parenchyme cells towards oxygen concentration degree along the sinusoid. The three concentric zones in liver asinus are: Zone 1, ellipse area directly surrounding capillary branch of the portal area; Zone 3, area at the ends of asinus; and Zone 2 , the area between Zone 1 and Zone 3 . Liver asinus has a functional meaning, i.e. a structural unit that is connected to the cell degeneration pattern in hypoxic and toxic injuries in the liver. ${ }^{14}$

The damage of the liver cells due to paracetamol toxic effect happens in the area around central vein as the lobule center (centrilobular area) according to the classic liver lobule concept or in Zone 4 according to the liver asinus concept. The damage in the centrilobular/ zone 3 asinus area is caused by drug metabolism process and creates potentially toxic metabolic substance, e.g. in paracetamol metabolism. ${ }^{2}$

Paracetamol biotransformation processes happen in the liver with most of them are conjugated by glucporonate, some are conjugated by sulphate and others are hydroxylated to form highly reactive metabolite, which is also toxic, $\mathrm{N}$-asetil-p-benzoquinoneimin $/ \mathrm{N}$-acetyl- $\mathrm{p}$ benzoquinoneimine (NAPQI). The metabolites, which are the free radicals, are not dangerous in normal dose.

Hepatotoxicity may happen in single dose paracetamol provision of $10-15 \mathrm{~g}(200-250 \mathrm{mg} / \mathrm{kg}$ weight) while a single dose of $20-25 \mathrm{~g}$ or more can cause direct death. The interaction with consumed alcohol will make the hepatotoxicity more severe. ${ }^{5}$ 
The damage in liver cells caused by the use of paracetamol often happens through reactive metabolites formed by paracetamol metabolism by liver cell oxidation system, i.e. cytochrome P-450. The metabolite called $\mathrm{N}$ asetil-p-benzoquinoneimine actually undergoes detoxificatin process by the liver by binding with glutation which is then exreted through the kidney. However, if this metabolite is formed in high quantity due to high dose paracetamol use, the glutation level in the heart will be less so that the metabolite will experience deposition in the cell and, finally, will be bound covalently with liver cell macromolecule. The covalent binding with proteins and nucleic acids of the liver cells increases drug toxicity and will destroy cell membrane structure. ${ }^{4,8}$

Stable and intact membrane cell structure is very important for the live of a cell. The damage of cell membrane is the main factor that makes a damaged cell cannot be fixed or recovered to normal. One of the important mechanisms in the process of cell membrane damage is a damage triggered by free radicals.

Energy is produced by cells through reduction of oxygen molecules into water moleculers. This reduction process produces a small amount of reduced oxygen that is reactive as the side products with some of them are free radicals that can damage lipid, protein and cell DNA structures. The cell damages caused by free radicals can be caused by physiological factors, such as cell aging, and pathological factor such as chemical exposure, radiation exposure, ischemic injury. ${ }^{4}$

Free radicals are atoms or atom groups that have one or more electron with no pair leading them to become very reactive. In this group there are peroxil group (ROO), hydroxil group $\left(\mathrm{OH}^{-}\right)$and anion superoxide $\left(\mathrm{O}_{2}^{-}\right) .^{9}$

Liver is an organ with certain mechanism that is normally do metabolism process to toxic agents. Toxic agents in the form of reactive metabolite are changed into $\mathrm{H}_{2} \mathrm{O}_{2}$. The reaction can be explained using the following formulation:

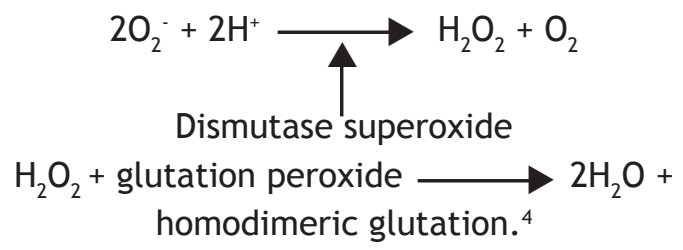

In Group III mice, they received paracetamol for 5 days and on day 7 they received apple juice. The number of necrotic cells is lower than group II who only received paracetamol treatment for 5 days. Observation on day 9 and day 11 showed the number of necrotic liver cells was smaller in the two groups compared to the number in day 7. A similar thing happens in the comparison between the two groups, showing that the number of necrotic celss in Group III was smaller than those in Group II.

The difference in the number of necrotic liver cells in each group on different observation day showed the effect of duration to the regeneration process of the liver cells. This was shown that the later the observation day, the fewer necrotic liver cells seen in each group. This was supported by Leeson et al. ${ }^{3}$ statement that a lot of mitotic activities in liver parenchym cells are found during recovery after an injury.

The regeneration ability of the liver cells after injury is very high, and the existing cells still have hypertrophic and hyperplasia abilities. The same was stated by Robbins et al. ${ }^{4}$ that the liver parenchymal cells were included in a stable cell group, meaning that these cells have high mitotic ability that will only occurs when there is tissue damage.

In addition, the differences in the amount of necrotic liver cells between the two group on each observation day was predicted to be an effect of the antioxidant activity of the apple juice. This was shown by the number of necrotic liver cells which was smaller in group III compared to group II on every observation day.

Naturally, antioxidant can be found in the body as the body protector agent that protects the body from negative effects of free radicals. The presence of disturbance or inability of body antioxidation system to deal with free radical oxidation can lead to various types of disease. The main prevention for free-radical triggered disease or antioxidation system imbalance is by consuming antioxidant agents. ${ }^{15}$

Antioxidant agent can contribute electrons to neutralize free radicals that can damage cells. Free radical molecules have unpaired electrons, making them unstable and very reactive. This may cause continuing reaction that wil goes on until the free radicals become stable because of reactions with other free radicals or with antioxidant. ${ }^{9}$ 
Nutrition agent that has antioxidant effect and works effectively is vitamin C. The best vitamin $C$ source is fresh fruit including fruit extract/juice that cannot be replaced by vitamin $\mathrm{C}$ in the form of supplement. ${ }^{11,15}$

Apple is one of the important sources of antioxidant becaue it relates to less risk for getting diseases caused by free radicals. ${ }^{13}$ Hernani and Rahardjo ${ }^{12}$ also stated that apple is one of the fruit that has the highest antioxidant nature compard to other fruits. In 100 gram fresh apple, $500 \mathrm{mg}$ antioxidant agent in the form of vitamin $C$ is found.

\section{CONCLUSION}

Based on the results of the study, it can be concluded that apple juice can prevent further damage and repair damages in liver cells caused by paracetamol consumption. This was shown by the finding that giving $1 \mathrm{ml}$ apple juice for six days to the mice in treatment group can reduce the number of necrotic liver cells compared to the intoxicated group.

\section{REFERENCES}

1. Hadi S. Gastroenterologi. $7^{\text {th }}$ ed. Bandung: Alumni; 2002.

2. Stevens A, Lowe J. Pathology. $2^{\text {nd }}$ ed. Edinburgh: Mosby; 2000.

3. Leeson CR, Leeson TS, Paparo AA. Textbook of histology. $5^{\text {th }}$ ed. Jakarta: EGC; 1996.

4. Robbins SL, Cotran RS, Kumar V, Abbas AK, Fausto N. Robbins and Cotran pathologic basis of disease. $7^{\text {th }}$ ed. Philadelphia: Elsevier Saunders; 2005.

5. Roberts LJ, Morrow JD. Analgesic-antipyretic and anti-inflammatory agents and drugs employed in the treatment of gout. In: Goodman and Gilman's the pharmacological basis of therapeutics. $10^{\text {th }}$ ed. New York: McGraw-Hill; 2001. p. 687-731.

6. Wilmana PF. Analgesik-antipiretik analgesik anti-inflamasi nonsteroid dan obat pirai. In: Farmakologi dan terapi. $4^{\text {th }}$ ed. Jakarta: Farmacology Department Faculty of Medicine Universitas Indonesia; 2005. p 207-22.

7. Bayupurnama P. Hepatotoksisitas imbas obat. In: Buku ajar ilmu penyakit dalam. $4^{\text {th }}$ ed. Jakarta: Pusat Penerbitan Departemen IImu Penyakit Dalam Fakultas Kedokteran Universitas Indonesia; 2006. p. 471-4.

8. Podolsky DK, Isselbacher KJ. Kekacauan metabolisme hati. In: Harrison's principles of internal medicine. $13^{\text {th }}$ ed. Jakarta: EGC; 2000. p. 1626-33.

9. Susanto B. Efek proteksi antioksidan terhadap radikal bebas. Maj IImiah Widya 1997;14:139,24-8.

10. Lata B, Trampczynska A, Oles M. Antioxidant content in the fruit peel, flesh and seeds of selected apple cultivars during cold storage. 2005. [cited 2009 Mar 15]. Available from: http: / /www.ptno.ogr.ar.krakow.pl/.

11. Wirakusumah ES. Buah dan sayur untuk terapi. Jakarta: Penebar Swadaya; 2006.

12. Hernani, Rahardjo M. Tanaman berkhasiat antioksidan. Jakarta: Penebar Swadaya; 2006.

13. Boyer J, Liu RH. Apple phytochemicals and their health benefits. 2004. [cited 2008 Nov 15]. Available from: http://www.nutritionj. $\mathrm{com} /$.

14. Fawcett DW. A Textbook of histology. $12^{\text {th }}$ ed. Jakarta: EGC; 2002.

15. Whitney E, Rolfes SR. Understanding nutrition. $10^{\text {th }}$ ed. Belmont: Thomson Wadsworth; 2005. 